\title{
Young adults' opinions of Philip Morris and its television advertising
}

\author{
L Henriksen, S P Fortmann
}

Tobacco Control 2002;11:236-240

See end of article for authors' affiliations

.....................

Correspondence to: Lisa Henriksen, PhD,

Stanford Center for

Research in Disease

Prevention, Stanford University School of

Medicine, 1000 Welch

Road, Palo Alto, CA

94304, USA:

Ihenriksen@stanford.edu

Received

8 February 2002

and revision requested 21

April 2002. Accepted 10

May 2002

\begin{abstract}
Objective: To determine what young people think about the tobacco company Philip Morris and how it affects their evaluations of the company's new television advertising.

Design: Data were gathered in the context of a controlled experiment in which participants saw four Philip Morris ads about youth smoking prevention, four Philip Morris ads about charitable works, or four Anheuser-Busch ads about preventing underage drinking (the control group). Knowledge and opinion of Philip Morris were measured before ad exposure.

Setting: A California state university in the San Francisco Bay area.

Subjects: A convenience sample of undergraduates $(n=218)$ aged $18-25$ years.

Main outcome measures: Advertising evaluation measured by 12 semantic differential scales.

Results: A little more than half of the students knew that Philip Morris is a tobacco company. Neither this knowledge nor students' smoking status was related to their opinion of the company. Philip Morris ads were rated less favourably by students who were aware that the sponsor is a tobacco company than by students who were unaware.

Conclusions: Advertisements designed to discredit the tobacco industry typically avoid references to specific companies. This study suggests that such counter-advertising would benefit from teaching audiences about the industry's corporate identities.
\end{abstract}

$\mathrm{T}$ he world's largest tobacco company, Philip Morris, is engaged in an unprecedented effort to rehabilitate its image. In 1998, the company launched a national media campaign to advertise itself as a proponent of youth smoking prevention. The $\$ 100$ million venture identifies Philip Morris USA as the source of several television commercials aimed at youth (with the slogan "Think. Don't smoke.") and parents (with the slogan "Talk. They'll listen."). A second campaign (with the slogan "Working to make a difference, the people of Philip Morris") publicises the company's efforts to prohibit cigarette sales to minors, as well as its charitable works on behalf of the elderly, homeless teens, and victims of domestic violence, Midwestern floods, and war torn Bosnia. Until now, Philip Morris had not advertised on television since 1971. In effect, these ads portray the first positive images of the company on television in 30 years.

The goal of this research is to examine young people's perceptions of the world's largest tobacco company and its television advertising. This paper addresses the following research questions: What do young people know and think about Philip Morris? Is their opinion of Philip Morris related to their smoking status or awareness that the company manufactures cigarettes? How does knowing that Philip Morris is a tobacco company affect young people's evaluations of its advertising?

Few studies have examined young people's memory and evaluations of new television ads sponsored by Philip Morris. In the first study to address this issue, focus groups of teenagers (grades 7-10, ages 12-16 years) compared 10 smoking prevention ads from campaigns sponsored by Arizona, California, Florida, Massachusetts, and Philip Morris. ${ }^{1}$ When asked to guess which two ads were made by a tobacco company, more teens identified the Philip Morris ads than any of the other ads tested. In addition, teens rated the Philip Morris ads as being the least effective in motivating them to "stop and think about not smoking".

In a telephone survey of Massachusetts youth (ages 14-17 years), $19 \%$ of the 733 respondents described an ad from Philip Morris when asked to remember an anti-tobacco advertisement they had seen in the past month (unaided recall). ${ }^{2}$ Further, teens who recalled seeing a Philip Morris ad rated the ads less favourably than teens who recalled seeing a Massachusetts ad portraying illness or outrage regarding smoking.

Many more teens reported exposure to youth smoking prevention ads from Philip Morris in response to questions that measured cued recall. In a national telephone survey of youth aged 12-17 years, 70\% of respondents remembered a Philip Morris ad, $81 \%$ said it grabbed their attention, and 69\% said the ad was convincing. ${ }^{3}$ However, the ads from Philip Morris were found to be less memorable, less likely to grab attention, and less convincing than anti-smoking ads from the "Truth" campaign.

The focus of previous studies has been to compare youth smoking prevention ads sponsored by Philip Morris with ads sponsored by other (more credible) sources. This study extends previous research by comparing reactions to Philip Morris ads from youth who were either aware or unaware that the sponsor is a tobacco company. In addition, this is the first study we know of to examine viewers' responses to televised advertisements of a tobacco company's charitable works.

According to research on source credibility, evaluations of advertising depend, in part, on the perceived reputation of the sponsor. ${ }^{45}$ Advertising claims are more likely to be accepted when the sponsor is perceived to be trustworthy and honest. ${ }^{6}$ However, these traits are unlikely to be ascribed to a tobacco company. Indeed, the industry's reputation is tarnished by widespread news that tobacco companies lied about the addictive properties of nicotine and use deceptive marketing tactics to make their products attractive to youth. Thus, the primary study hypothesis predicts: (HI) Philip Morris advertisements will be rated less favourably by viewers who are aware the sponsor is a tobacco company than by viewers who are unaware.

\section{METHOD}

Young adults $(\mathrm{n}=218)$ enrolled in communication, business, and statistics courses at a California state university in the San 
Francisco Bay area participated in an experiment about the effect of corporate advertising campaigns on consumer attitudes. Data were collected between November 2000 and April 2001. The sample was ethnically diverse-33\% white, $26 \%$ Asian or Pacific Islander, 13\% African American, 12\% Hispanic, $16 \%$ other or multiple origins-and contained slightly more women (63\%) than men. Most of the sample (86\%) was between 18-25 years of age. Undergraduates are an appropriate study population for this research because 18 to 24 year olds are smoking at higher rates than in previous years, $^{7-9}$ and are a primary target of tobacco industry advertising. ${ }^{10} 11$

\section{Stimulus materials}

Television ads sponsored by Philip Morris were selected to represent the variety of ads about youth smoking prevention (advising youth not to smoke, encouraging parents to talk with their kids about not smoking, and a programme to discourage selling tobacco to minors*), and community service (aid to victims of domestic violence, homeless teens, and the elderly) that first aired in 1999 or 2000. The appendix describes each Philip Morris ad in the stimulus sets.

To disguise the focus on Philip Morris, several "filler" ads from other corporate advocacy campaigns were included. Ads sponsored by Anheuser-Busch were selected for their emphasis on preventing underage drinking, and ads sponsored by Pfizer and Chevron were selected for their emphasis on community service.

\section{Procedure}

Students were invited to participate in a study about corporate advocacy ads, which highlight a company's position on an issue rather than selling a particular product or service. ${ }^{12}{ }^{13}$ Active consent was obtained from all participants and the study protocol was approved by Stanford University's institutional review board.

Before viewing advertisements, an anonymous questionnaire solicited participants' thoughts and opinions about several corporations. Thus, participants' awareness that Philip Morris is a tobacco company and their opinion of the company were measured before advertising exposure was manipulated. All study participants saw four ads from corporate advocacy campaigns sponsored by Pfizer and Chevron. Random assignment determined whether participants then saw four Philip Morris ads about youth smoking prevention, or Philip Morris ads about charitable works, or Anheuser-Busch ads about preventing underage drinking (the control group). The videotape was stopped after each commercial while participants completed a brief evaluation of each ad. After exposure, participants responded to questions about the corporate sponsors and the industries they represent.

Data for this paper were drawn from a subset of items described below.

\section{Measures}

\section{Corporate identity}

Both open ended and multiple choice items were used to assess what students know about Philip Morris. The first item on the questionnaire asked students to "take a few minutes to write down what comes to mind when you think of the four companies listed below". Chevron, Anheuser-Busch, Philip Morris, and Pfizer were presented in the same order on all questionnaires. Students were advised to write "I don't know"

\footnotetext{
*Although an ad about the company's "We Card" programme features the slogan from the charitable works campaign, it was shown with other smoking prevention ads because its content emphasises reducing youth access to cigarettes.
}

if they had never heard of or did not know anything about a company. Responses were coded to indicate whether students expressed awareness that Philip Morris is a tobacco company.

A multiple choice item asked students to identify the product for which Philip Morris is best known. This item was repeated for Chevron, Anheuser-Busch, and Pfizer. For each company, students selected one answer from the same list of seven choices: soft drinks/sodas, beer, cigarettes, oil/gasoline, breakfast cereal, prescription drugs, clothing. Students who identified cigarettes were coded as having answered the question correctly, even though Philip Morris subsidiaries produce breakfast cereals and beer. To avoid this potential confusion, cereal and clothing were replaced by investment and internet services on a second version of the questionnaire. A $\chi^{2}$ test demonstrated that the proportion of correct answers did not differ significantly between the two versions so the data were combined.

\section{Pre-exposure opinion}

Before seeing any advertisements, students were asked to rate their opinions of Philip Morris on a five point scale from very positive to very negative. The midpoint of the scale was labelled "no opinion". The item was repeated for the three other corporations.

Opinion data were also derived from students' open ended responses about Philip Morris. Answers indicating awareness that the company manufactures tobacco were transcribed for further coding. Working independently, two coders judged the valence of responses as being negative (if respondents made any mention of diseases, death, deception, poor investment or stock performance), positive (if respondents made any mention of charitable works, good investment or stock performance), or neutral (if respondents made neither positive nor negative references to the company). Intercoder reliability for this judgment, measured by Cohen's $\kappa$, was 0.95 .

\section{Advertising evaluation}

A perceived effectiveness measure consisted of 12 semantic differential scales anchored at 1 and 6. The items asked students to indicate the extent to which each ad was "not at all" or "very" uplifting, moving, powerful, dishonest, effective, helpful, boring, deceptive, unconvincing, believable, informative, and annoying. These items were adapted from previous studies of public service announcements. ${ }^{14}$ Negatively valenced items were reverse scored before summing the scores and dividing by the number of items (Cronbach's $\alpha=0.89$ ).

Two additional items asked students to rate their familiarity with each ad on a four point scale and to estimate how many times they had seen each ad in the past month. The correlation between the two items ranged from 0.66 to 0.84 . This measure was included as a covariate to control for a priori differences in exposure to the ads of interest.

\section{Smoking status}

Students were identified as current smokers if they reported any smoking during the past 30 days and having smoked at least 100 cigarettes in their lifetime. Students were coded as "triers" if they indicated having smoked in their lifetime but not in the past 30 days.

\section{Analyses}

The $\chi^{2}$ test was used to examine associations between students' awareness that Philip Morris is a tobacco company, their opinion of the company, and their smoking status. To test the study hypotheses about advertising evaluations, data were analysed in a $2 \times 2$ repeated measures analysis of covariance (ANCOVA). Participants in a control group who watched Anheuser-Busch ads were excluded from this analysis because they did not evaluate any Philip Morris ads. One factor compared students who were either aware or unaware that 


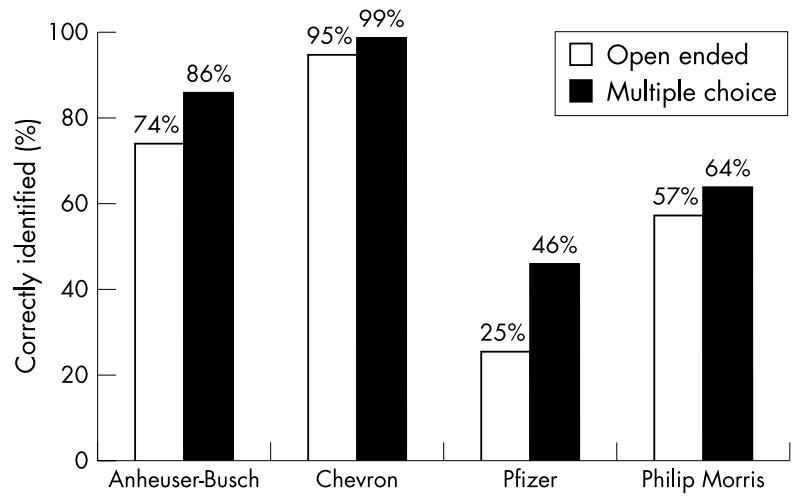

Figure 1 Corporate identity, measured by open ended and multiple choice items.

Philip Morris is a tobacco company. A second factor compared students who saw Philip Morris ads about youth smoking prevention with students who saw Philip Morris ads about charitable works. A within subjects factor with four levels was included to account for the fact that each participant was exposed to four advertisements. To control for students' prior exposure to Philip Morris ads and their opinion of the company, ad familiarity and pre-exposure opinion were entered as covariates.

\section{RESULTS}

\section{Philip Morris? I don'ł know him.}

When asked what comes to mind when they think of Philip Morris, approximately half $(57 \%)$ of students made some mention of tobacco. Certain incorrect guesses were noteworthy. Several students identified Philip Morris as a well known talent agency (perhaps a reference to William Morris) or the maker of upset stomach medication (probably thinking of Phillips' Milk of Magnesia). Others associated Philip Morris with light bulbs, TV sets, and CD players (likely referring to Philips Electronics). One student mentioned that Philip Morris was famous for its tools-perhaps thinking of the Phillips head screwdriver. Very few students volunteered the kind of scepticism about Philip Morris and its advertising that is a focus of California's tobacco education campaign. For example, one student wrote: "Cigarette company. Tried to deny that smoking causes cancer. Friendly ads that try to convince population that they are good corporate citizens-I don't believe them though." Another student juxtaposed the company's charitable works with its profit making enterprise: "Ads showing how they contribute [money] to good causes [with] no mention of how many people die from using their products." A similar response mentioned: "beer, cigarettes, cover-up commercials, trying to help the community when at the same time they're poisoning the community by selling beer and cigarettes." Only one student was aware that Philip Morris "spend[s] more money on TV ads than on actual donations".

When selecting from a multiple choice list, the proportion of correct answers associating Philip Morris with tobacco increased from $57 \%$ to $64 \%$ (fig 1). Approximately $20 \%$ of students selected investment services, $5 \%$ prescription drugs, and $1-2 \%$ selected every other option (that is, clothing, internet service, beer, breakfast cereal, oil/gasoline, and soft drink/ sodas). As fig 1 illustrates, Philip Morris was not as well known to students as Anheuser-Busch and Chevron, but better known than Pfizer.

Not surprisingly, smokers were more likely than nonsmokers to know that Philip Morris is a tobacco company $\left(\chi^{2}=6.49, \mathrm{p}<0.05\right)$. According to their open ended responses, $71 \%$ of current smokers, $60 \%$ of triers, and $49 \%$ of students who never smoked knew that Philip Morris was a tobacco company.



Figure 2 Effect of ad type and corporate identity on ad evaluations.

The proportions who correctly identified tobacco from a multiple choice list were $77 \%$ of current smokers, $70 \%$ of triers, and $53 \%$ of never smokers $\left(\chi^{2}=10.0, \mathrm{p}<0.01\right)$.

\section{Pre-exposure opinion}

When asked to rate their opinion of Philip Morris, $16 \%$ of the students rated the company positively, $28 \%$ were neutral, and $56 \%$ rated the company negatively. However, students' open ended responses yielded surprisingly few negative comments about Philip Morris. Of the 125 students whose answers demonstrated some awareness that Philip Morris is a tobacco company, $30 \%$ ( $17 \%$ of the total) either associated Philip Morris with tobacco related disease and death or volunteered comments about deceptive marketing tactics. Typical statements were: "major cause of untimely deaths", "lung cancer", "definitely bad for your health", "denies that smoking is addictive", and "their fortune comes from the people they hooked on to their cigarettes". Of the 125 students whose responses indicated that Philip Morris manufactures tobacco products, $17 \%(10 \%$ of the total) volunteered positive comments about the company, such as "really good stock to own", "does great things for community", "very successful", and "nice advertising".

There was no association between students' opinion of Philip Morris and their smoking status $\left(\chi^{2}=1.7, p=0.42\right)$. Among non-smokers, 57\% expressed a negative opinion, $29 \%$ had no opinion, and $14 \%$ expressed a positive opinion of the company. Among smokers, the distribution was 52\% negative, $25 \%$ neutral, and $23 \%$ positive. Similarly, there was no association between students' opinion of Philip Morris and their awareness that the company manufactures tobacco $\left(\chi^{2}=2.2\right.$, $\mathrm{p}=0.33$ ). Among students who selected cigarettes as the product for which Philip Morris is best known, 59\% expressed a negative opinion, $27 \%$ had no opinion, and $14 \%$ were positive. Among students who associated Philip Morris with a product other than cigarettes, $51 \%$ expressed a negative opinion, $29 \%$ had no opinion, and $16 \%$ were positive.

\section{Advertising evaluation}

Figure 2 illustrates the effect of viewers' knowledge that Philip Morris is a tobacco company on their evaluation of its advertising. The analysis excludes data from the control group who saw Anheuser-Busch ads about preventing underage drinking. Viewers' knowledge was determined by volunteering a reference to tobacco in response to the open ended question about Philip Morris. This was considered to be a more conservative measure of corporate awareness and had the advantage of maximising equal cell sizes. $\dagger$ Smoking status

†Substituting the multiple choice response as an indicator of knowledge yielded the same results but a more unbalanced design. 
Table 1 Mean (SD) evaluation for each message by ad type and corporate identity

\begin{tabular}{llll}
\hline & \multicolumn{2}{l}{$\begin{array}{l}\text { Aware that Philip Morris } \\
\text { is a tobacco company }\end{array}$} \\
\cline { 2 - 3 } & Yes & No & (d) \\
\hline Smoking prevention & $\mathrm{n}=32$ & $\mathrm{n}=36$ & \\
"We Card" programme & $3.4(1.2)$ & $4.0(1.1)$ & 0.55 \\
Teen listens to her parents & $4.0(1.0)$ & $4.4(0.9)$ & 0.41 \\
Father-daughter talk & $4.1(1.0)$ & $4.5(0.8)$ & 0.45 \\
City kids decide for & $3.5(1.1)$ & $4.2(0.8)$ & 0.78 \\
themselves & & & \\
& & & \\
Charitable works & $n=48$ & $n=33$ & \\
Domestic violence & $4.0(1.0)$ & $5.1(0.6)$ & 1.30 \\
Food bank & $3.6(1.0)$ & $4.6(0.8)$ & 1.10 \\
Shelter for homeless teens & $3.6(1.1)$ & $4.7(0.8)$ & 1.10 \\
Meals on wheels & $4.0(1.0)$ & $4.8(0.9)$ & 0.86 \\
\hline Higher numbers indicate more favourable ratings (maximum $=6)$.
\end{tabular}

was not included in the model because smokers and non-smokers did not differ significantly in their opinions of ads about smoking prevention or charitable works.

As predicted, Philip Morris ads were rated more favorably by viewers who were unaware the sponsor is a tobacco company (mean (SD) $4.53(0.75))$ than by viewers who were aware (3.77 (0.89)), $\mathrm{F}_{1,141}=34.9, \mathrm{p}<0.001$. The difference between these two types of viewers appeared larger among those who saw ads about the company's charitable works than among those who saw ads about youth smoking prevention; however, the interaction was not significant $\left(F_{1,141}=3.6\right.$, $\mathrm{p}=0.06)$. Ads about charitable works $(4.2(0.95))$ received more favourable evaluations than ads about youth smoking prevention (4.0 (0.86), $\left.\mathrm{F}_{1,141}=5.1, \mathrm{p}<0.05\right)$, although the mean difference was not large.

Table 1 compares the evaluations of each advertisement for viewers who were either aware or unaware that Philip Morris is a tobacco company. This knowledge had a moderate to large effect on the perceived effectiveness of Philip Morris advertising. A consistent pattern emerged for ads about charitable works. Each ad was rated significantly less favourably by viewers who knew the sponsor is a tobacco company. Although the same pattern emerged for ads about youth smoking prevention, the difference between evaluations from the two types of viewers was significant for only two of the four ads.

\section{DISCUSSION}

This is the first study we are aware of to estimate the proportion of young adults who know that Philip Morris is a tobacco company and to examine how this knowledge affects evaluations of the company's television advertising. The proportion of young adults who identified Philip Morris as a tobacco company ranged from 57-64\%, depending on how their knowledge was measured. When compared to knowledge of other corporate identities, this result is larger than one might expect. For example, the percentage of students who correctly identified Pfizer-a pharmaceutical company that launched a corporate identity campaign ("Life is our life's work") about the same time as Philip Morris—ranged from $25-46 \%$. However, the result is smaller than one might expect from young adults living in a state with an aggressive anti-tobacco media campaign. Indeed, tobacco control advocates may be disappointed to learn that any student was unaware Philip Morris is a tobacco company.

The students' opinion of Philip Morris was measured before exposure to the company's advertising. Almost one third of students said they had no opinion of Philip Morris, which makes them an ideal audience for a persuasive campaign designed to overhaul the company's image. Although about half of the students rated Philip Morris negatively, it is surprising how few of them volunteered negative comments about the company. When asked what comes to mind when they think of Philip Morris, students typically mentioned tobacco without commenting on its marketing or the consequences of its use. Few of the students' responses reflected the criticisms of the tobacco industry that have been a defining feature of California's anti-smoking media campaign.

Opinions of Philip Morris were unaffected by students' smoking status - that is, positive opinions of the company were only slightly more common among smokers than non-smokers. We expected smokers to think more positively of Philip Morris than non-smokers. Perhaps smokers in fact feel some resentment toward their "supplier" to the degree that they feel addicted to tobacco. Smokers' negative opinion of a tobacco company may also reflect their desire to quit.

The primary study hypothesis concerns the effect of knowing that Philip Morris is a tobacco company on viewers' evaluations of its advertising. As predicted, Philip Morris ads were rated less favourably by students who were aware that the sponsor is a tobacco company than by students who were unaware. This was true for advertisements about charitable works as well as for ads about youth smoking prevention.

The small size and nature of the sample are the primary limitations of this study. It is not known how well the study findings generalise to other young adults living in California or in states without an anti-tobacco media campaign. Surveying a larger, more representative sample would more accurately estimate young adults' knowledge about tobacco companies and opinions of their advertising. The artificial nature of participants' exposure is another limitation of the study design. This aspect of a controlled experiment limits the ability to draw conclusions about young adults' reactions to Philip Morris television advertising in the course of their everyday lives.

Ideally, the presentation order of the advertisements would be randomised for each study participant. Because participants saw ads in the same presentation order, inferences about the effectiveness of individual ads must be made with caution. Evaluations of particular ads cannot be disentangled from the effects of their serial position in the stimulus set. However, participants' exposure to multiple ads strengthens conclusions about the two Philip Morris campaigns.

Asking students what they know and think about Philip Morris before evaluating the company's advertising raises concern about demand characteristics-that the experiment primed participants to evaluate the ads more negatively. Two reasons make priming an unlikely explanation for the results. Firstly, between giving an opinion about Philip Morris and rating its advertisements, students evaluated multiple ads from other companies. Thus, considerable time (at least 15 minutes) and new content was introduced between measuring students' opinion of Philip Morris and its advertising. Secondly, the analysis of ad evaluations controls for students' pre-exposure opinion of the sponsor. Future research should consider the impact of telling the audience that Philip Morris manufactures and markets cigarettes.

Results from this study suggest that more sceptical responses to the Philip Morris campaigns could be encouraged by teaching young adults about the sponsor's identity. This recommendation contradicts common practice in antismoking advertising. Indeed, anti-industry ads typically avoid references to specific tobacco companies. In particular, advertising funded by the settlement between the tobacco companies and the US attorneys general is precluded from vilifying specific tobacco companies. ${ }^{16}$ Without mentioning Philip Morris specifically, recent ads from the California Department of Health Services refer to the tobacco company's corporate image campaign: "We don't say anything about 
'cigarettes' on the tube. We talk about beer, we talk about cheese, and we talk about community service." Research is needed to determine whether such oblique references to Philip Morris are understood and are sufficient to engender scepticism about the company's advertising.

Data for this study were collected before Philip Morris shareholders voted to change the company's name to The Altria Group. The proposed name change is significant because it distances the parent company's reputation from that of its tobacco subsidiary. This study suggests that it is incumbent upon tobacco control advocates to teach the public that The Altria Group has more to do with tobacco than altruism.

\section{ACKNOWLEDGEMENTS}

This research was supported by a grant from California's TobaccoRelated Disease Research Program, 9RT-0138. The authors wish to thank their research assistants, Emily McChesney Gonzalez and Harry Haladjian, as well as Carla Corral, Nina Schleicher, and Valerie Sue for help with data collection.

\section{APPENDIX}

\section{Youth smoking prevention}

"We Card" Program (30 seconds)-The owner of a small grocery store explains that refusing to sell cigarettes to teens is made easier by the "We Card" programme. When a group of teens dressed for the prom attempt to buy cigarettes, the store owner refuses as he points to a "We Card" sign. A female voiceover tells the audience that Philip Morris, a major sponsor of the "We Card" programme, is committed to keeping cigarettes out of the hands of teens. Tagline is "working to make a difference, the people of Philip Morris".

Teen listens to her parents ( 30 seconds) — A young Asian female, standing alone with a white background, talks to the camera as if she is addressing her mom. She says that as she gets older, she still thinks about what her mother has taught her, including the reasons why not to smoke and how to say "no". So when someone asks her if she wants a cigarette, she thinks about her mother's words even though she is not there. Tagline is to "talk to your kids about smoking, they'll listen".

Father-daughter talk (30 seconds) - A teenage girl walks into the kitchen, getting ready to go out on a group date. Her father reminds her of the rules for the evening: curfew, no drinking, and no smoking. The door bell rings and the teen goes out. The teenage girl and her friends are walking down the street in a suburban setting. A teenage boy asks her if she wants a cigarette, and she politely refuses. The narrator tells the audience, "Talk to your kids about smoking, they'll listen".

City kids decide for themselves (30 seconds) - Different groups of teens talk about how they know "what's going on" and that "it's not cool to smoke". They are shown in different settings: parks, in the streets of a large city, on a computer, at the movies. One African American teen says that his decision not to smoke was not the most difficult decision to make. Another teen tells the audience to give them "some credit for a change". Tagline is "Think. Don't Smoke".

\section{Charitable contributions}

Domestic violence ( 60 seconds) - This ad begins with a dramatic close up of a white pregnant woman with a black eye and bloody face and arms. She explains that her husband beat her and almost hurt her young son with a knife, and how she was forced to move into a shelter. A female voiceover tells the audience that the Philip Morris companies donate money to help victims of domestic violence start new lives, as images of a peaceful shelter and happy children playing are shown. The battered woman says that she is glad she left her home to give her children the opportunity to live in a loving home. Tagline is "working to make a difference, the people of Philip Morris".

Food bank (30 seconds) - An elderly African American woman sits in a sunny kitchen peeling a tangerine and tells how thankful she is for the food brought to her by the people at a food bank. As the woman peels and happily eats the tangerine, a female voiceover explains that Kraft and Philip Morris have been donating food for over 20 years to help fight hunger. Tagline is "working to make a difference, the people of Philip Morris".

Shelter for homeless teens (60 seconds)-Homeless teens are shown sleeping under a bridge, walking down a city street, and sitting in an abandoned car as a voice-over talks about teenage "throwaways". A woman from "Crossroads Teen Shelter" explains that when

\section{What this paper adds}

Previous studies have compared youth smoking prevention ads sponsored by Philip Morris with ads sponsored by other (more credible) sources. This study extends previous research by comparing reactions to Philip Morris ads from youth who were either aware or unaware that the sponsor is a tobacco company. In addition, this is the first study we know of to examine viewers' responses to televised advertisements of a tobacco company's charitable works.

she ran out of funds for rebuilding a home to shelter homeless teens, Philip Morris sent enough money to finish the project. A female voiceover tells how Philip Morris knows that many people are in need and they have been donating to help these causes over the past 10 years. Tagline is "working to make a difference, the people of Philip Morris".

Meals on wheels ( 30 seconds) - A driver delivers a meal to an elderly woman at home and sings her Italian love songs. A female voiceover says that Philip Morris gives grants to organisations such as Meals on Wheels so that money is available to deliver food to needy seniors. While the driver and woman are shown holding hands and laughing, the voiceover says that the people of Philip Morris not only fight hunger, they fight loneliness. Tagline is "working to make a difference, the people of Philip Morris".

\section{Authors' affiliations}

L Henriksen, S P Fortmann, Stanford Center for Research in Disease Prevention, Stanford University School of Medicine, Palo Alto, California, USA

\section{REFERENCES}

1 Teenage Research Unlimited. Counter-tobacco advertising exploratory: summary report. Northbrook, Illinois: Teenage Research Unlimited, 1999.

2 Biener L. Anti-tobacco ads by Massachusetts and Philip Morris: what teenagers think. Tobacco Control 2002;11 (suppl II):II43-6.

3 Healton C. Who's afraid of the truth? Am J Public Health 2001;91:554-8.

4 Lutz RJ. Affective and cognitive antecedents of attitude toward the ad: a conceptual framework. In: Alwitt LF, Mitchell AA, eds. Psychological processes and advertising effects: theory, research, and applications. Hillsdale, New Jersey: L. Erlbaum Associates, 1985:45-63.

5 MacKenzie SB, Lutz RJ. An empirical examination of the structural antecedents of attitude toward the ad in an advertising pretesting context. Journal of Marketing 1989;53:48-65.

6 Goldberg ME, Hartwick J. The effects of advertiser reputation and extremity of advertising claim on advertising effectiveness. Journal of Consumer Research 1990;17:172-9.

7 Emmons KM, Wechsler H, Dowdall G, et al. Predictors of smoking among US college students. Am J Public Health 1998;88:104-7.

8 Rigotti NA, Lee JE, Wechsler H. US college students' use of tobacco products: results of a national survey. JAMA 2000;284:699-705.

9 Wechsler H, Rigotti NA, Gledhill-Hoyt J, et al. Increased levels of cigarette use among college students: a cause for national concern. JAMA 1998;280:1673-8.

10 RJ Reynolds Tobacco Company. Camel advertising development "white paper". RJ Reynolds Tobacco Company Online Litigation Document Archive. 1987. Accessed 27 February 1998. Document No: 506742 179-2 188. URL: http://www.rirtdocs.com/rirtdocs/.

11 Sepe E, Glantz SA. Bar and club tobacco promotions in the alternative press: Targeting young adults. Am J Public Health 2002;92:75-8.

12 Fox KFA. The measurement of issue/advocacy advertising effects. In: Leigh J, Martin CR, eds. Current issues and research in advertising. Ann Arbor, Michigan: University of Michigan Business School, 1986.

13 Haley E. Exploring the construct of organization as source: consumers understandings of organizational sponsorship of advocacy advertising Journal of Advertising 1996;25:19-36.

14 Austin EW, Pinkleton B, Fujioka Y. Assessing prosocial message effectiveness: effects of message quality, production quality, and persuasiveness. Journal of Health Communication 1999;4:195-210.

15 Hammond SL. Health advertising: the credibility of organizational sources. In: McLaughlin M, ed. Communication yearbook 10. Newbury Park, California: Sage Publications, 1987

16 National Association of Attorneys General. Master settlement agreement: proposed settlement of state cases; section VI (h); 1998 December 8. 